\title{
Using Role-Play Technique To Teach Speaking Skill Procedure Text In Tourism Management Department
}

\author{
Putu Ngurah Rusmawan, putungurahrusmawan@poliwangi.ac.id, Politeknik Negeri \\ Banyuwangi
}

\begin{abstract}
In the revolution industry, era 4.0 required the student in the tourism department to enable speak English as an international language fluently. The students need to improve their communication skills. The role-play technique is one teaching technique that is applicable in-state polytechnic of Banyuwangi because it focused on practicing real-life communication skills. The researcher tried to investigate the teaching speaking activity in the classroom. The study used descriptive qualitative research. The researcher analyzed and described the teaching speaking in procedure text by using role-play technique for the tourism department. The preparation of the lecturer was syllabus and learning contract, which contained teaching materials, the method, and learning sources. The process of teaching divided into three steps; they were pre-activity, main activity, and post-activity. He brought them in class. The lecturer used roleplay techniques. The lecturer only facilitated the students to be active in speaking procedure text. He asked the students to do simulation communication in a hotel. One of the students plays a role as receptionist and the other as a customer. During the teaching-learning process, the lecturer got three main troubles in conducting the teaching process. They were students' low in vocabulary, pronunciation, and trouble in expressing sentences, and the lecturer had done the solution. Speaking procedure text course, which was taught by the lecturer, proceeded effectively and acceptable for the students.
\end{abstract}

Keywords: Role-play, Speaking, Procedure text

\section{INTRODUCTION}

Smart in using international language in the industrial era revolution 4.0 can not be avoidable. Language is a tool to express, to exchange, and to share the idea in expressing something(Yule, 2010). Therefore, a human requires to use language as communication devices to exchange their thought(Brown, 2007). English is an international language that must be mastered by students in the tourism department to open the international communication tourism gate. The students need to increase their communications speaking skills. They must master good communication skills to serve the international guest, such as: making a hotel reservation online, welcoming the international guests, tour guiding, and making services well. That is why the reason of being the success of the students in a tourism department in state polytechnic of Banyuwangi should drill. They had to master English as international communication. The students need to know English since their beginning level of education, which can improve their skills in speaking. By learning and practicing English from the early, the students can have a basic knowledge of English. The students in the tourism department must be capable of communicating well.

There are four skills in English that the students in the tourism department should master to be able to communicate well in English. They are speaking, listening, reading, and speaking. Among the four skills has been mentioned previously, speaking skill is the most

96 | IJET $\mid$ Volume. 9, Issue 1. July 2020

Copyright 2020 Putu Ngurah Rusmawan is licensed under Creative Commons Atrribution-ShareAlike 4.0 International License. 
needed to be focused because, in speaking, students must provide effective and polite services. Speaking is a crucial skill to be needed for the student(Harmer, 2007). Brown (2007) adds that teaching speaking skills is a complex job because lecturers need to think of creative and innovative teaching techniques. They must produce an effective teaching technique to improve students' communicative skills.

During learning a speaking skill, the students need to comprehend some type of text. They are recount, procedure, descriptive, and report text-in-state Polytechnic of Banyuwangi, those text genres discussed in general. According to the learning contract and course syllabus of general English subject for tourism students, especially in state polytechnic of Banyuwangi, students must understand in general about procedure text about how to serves the guest politely. So, this paper focused on speaking procedure text. A procedure text is telling text that contains a sequence of events that occurs over time(Anderson \& Anderson, 2003). In this research, the procedure text referred a procedure about how to check-in and check out, to book a hotel room, to get the best service for food and beverage in a restaurant hotel, to know the hotel facility, price, and service.

Many teaching techniques had been applied to teaching and learning English in Indonesia. The ideal technique that widely used in teaching speaking is using role-play. It is was very practical in teaching speaking because it serves students a chance to communicate in different social contexts and different social roles (Ur, 2012). Role-play would seem to be the ideal activity in which students could use their English creatively, and it aimed to stimulate a conversation situation. The students might found themselves and allowed them to practice and develop their communication skills.

The researcher selects the best class for the observation. Based on the lecturer's information, the students have prestigious awards in English festivals and competitions. Most students are discipline, have high motivation, and enjoy learning English. Based on the reason above, the researcher wants to investigate research with the title using role-play technique to teach speaking skill procedure text in tourism students of state polytechnic of Banyuwangi.

Based on the condition shown in the background of the study, the researcher formulates the problems into:

1. What does the lecturer's preparation prepare before conducting the teaching speaking?

2. How does the lecturer teach speaking skills by using role-play techniques in the tourism department?

3. What are the lecturer's and the students' problems during teaching and learning to speak?

4. How is the students' response to procedure text in learning speaking at the tourism department?

5. How does the lecturer evaluate the students in learning speaking procedure text in the tourism department?

Based on the problem of the study, the researcher had the objectives of the study are:

1. To know the lecturer's preparation before conducting the teaching speaking in procedure text at the tourism department.

2. To know how the lecturer teaches speaking procedure text trough role- play at the tourism department.

3. To know the lecturer's and the students' problems in teaching and learning speaking procedure text at the tourism department.

4. To know the students' responses to procedure text in learning speaking at the tourism department. 
5. To know the lecturer evaluate the students in learning speaking procedure text at the tourism department.

The result of this research expects to give important things for the development of the English teaching and learning process. This significance is for the English lecturers and other researchers.

\section{The Lecturer}

The lecturer of English can get information from the teaching of speaking in procedure text. They can read the result of the research and find the best technique in the teaching procedure text.

2. The Future Researchers

The future researcher can use this thesis as a reference for the future or other researchers in a similar study on the same field.

This study focuses on teaching and learning on speaking procedure text, especially in the role-play application on the teaching speaking procedure. It is about the lecturer's preparation, how the lecturer teaches used role-play on education speaking in procedure text, the problems of the lecturer and student, the students' responses about procedure text in learning speaking, how the lecturer evaluates the students in learning speaking procedure text at To be more specific, the researcher conducted this research in the first semester students of tourism department which consists of 34 students, ten male, and 24 female students.

\section{METHOD}

Based on the research question above, the researcher analyzed and described the teaching speaking in procedure text by using role-play technique for the tourism department. The researcher tried to investigate the teaching speaking procedure text activity in the classroom. The study used descriptive qualitative research as the research method. According to Creswell (2014), qualitative research was the best design to solve the research problem. The researcher recognized the variables and phenomena in classroom activities that needed to explore. Johnson (2007) also argued that a qualitative research study was needed to explore this phenomenon from the perspective of distance education students.

In this research, the researcher observed and described events that might happen in the class. From the objective above, the researcher observed the lecturer's preparation, the lecturers teaching speaking activities by using role-play, the lecturer's and the students' problems in teaching and learning to speak, the students' response in teaching and learning to speak, and the lecturer evaluation of the students' speaking performance in speaking procedure text.

The subject of the research was on the first-semester students' tourism department, especially class A. The class consist of 34 students. There are ten males and 24 females. The state polytechnic of Banyuwangi located in Jl. Raya Jember Banyuwangi Kabat labanasem. The researcher used some types of instruments for this study to collect the data. They are interview, observation, questionnaire, and documentation. They emphasized on interviews, with six to eight members in each group. The interview was unstructured and open-ended questions that were in a few numbers, and it reflected the opinions from the lecturer. The researcher interviewed by face to face meeting between the researcher and the lecturer who teaches speaking procedure text in the first semester at the tourism department. It interview aimed to gain the information data about the implementation of the teaching speaking procedure text by using role-play technique.

The researcher used an interview because some of the questions had related to the research problem. It could be a piece of additional information and complete data about 
teaching and learning speaking procedure text. The interview consisted of 10 questions that must be answered by the lecturer. The researcher wrote all of the lecturer activities in field notes at the research site. The researcher observed the lecturer's preparation before teaching activities. He investigated how to teach speaking by using role-play in the procedure text. The researcher also observed the students' activity, whether they pay attention to the lecturer or not, active in answering questions, and show their motivation to speak in English. The researcher used guided observation. The researcher attended the class, and he sat at the back. He began to record the student's activities in his field note. The observation guide was for the English lecturer during the observation in the classroom meeting.

A questionnaire was the tool to collect the data about a particular issue of interest(Cresswell, 2014). It was a list of questions, and it was clear instructions. There was available space to be answered or administrative documented. Questionnaires should always have a definite purpose that had related to the objectives of the research. The researcher used the questionnaire to obtain the students' problems in the process of learning the speaking procedure. The questionnaire is the form of a close-ended question. It means that the researcher gave some questions as multiple choices. The questionnaire consisted of 10 questions that must be answered by the students. The questions were about how the lecturer teaches speaking, the technique used in teaching speaking, and also the students' problem in speaking procedure text.

The researcher used documentation to find out the lecturer's preparation before teaching the speaking procedure and the lecturer's way to evaluate the student speaking. The data collected from the English lecturer of state polytechnic of Banyuwangi about syllabus and learning contract was the documentation for collecting and supporting the data. These methods in line with(Cresswell, 2014), who gave the main methods in qualitative research into four parts, those are interview, observation, questionnaire, and documentation. In this study, the researcher collected the data interview, observation, questionnaire, and documentation.

The interview was given to the English lecturer to get data about the technique and the media. The researcher interviewed the lecturer on December 7th, 2019. The observation in the study conserved about the teaching and learning process of teaching-learning speaking procedure text. Those consist of the lecturers' observations checklist before the lecture began classroom activities in the classroom, and also the students' observation checklist in the classroom. The researcher observed classroom activities in two meetings. The researcher conducted the observation on December $11^{\text {th }}$ and $12^{\text {th }} 2019$.

The questionnaires were for the students'. The researcher gave the questionnaire on

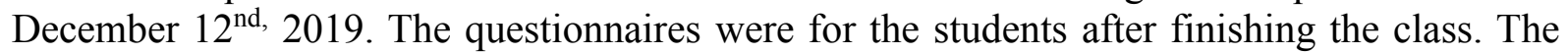
students answered the multiple-choice questions. After that, the researcher collected the questionnaires from the students. The researcher collected the data for documents the learning process by using a checklist - the data collected from the English lecturer. There were syllabus and learning contracts. The researcher also collected the data by attendance and photo documentation teaching and learning activities. Documentation finished on December 11th ${ }^{\text {st }}$, $12^{\text {nd }}$ and $13^{\text {th }} 2019$.

In this study, first, the researcher interviewed the lecturer about some questions before the class began. After class over, the second was the researcher did the observation during the class begin, which is to obtain the specific information about the teaching and learning process. Third, questionnaires were given to the students after the class finished. The last was the researcher collected the data by documentations about the preparation in teaching and learning speaking procedure text.

As mentioned before, the purpose of the research was to know the process of teaching speaking on the procedure. To analyze the data, the researcher used descriptive qualitative analyzing technique by following procedures:

99 | IJET $\mid$ Volume. 9, Issue 1. July 2020 Copyright 2020 Putu Ngurah Rusmawan is licensed under Creative Commons Atrribution-ShareAlike 4.0 International License. 
1. The researcher analyzed the data from the interview between the researcher and the lecturer. It means that the researcher interpreted the interview and made the conclusion related to the information about the lecturer preparation, how the lecturer teaches through role-play, the lecturer and the student problem, and also how the lecturer evaluated the students' work.

2. The researcher analyzed the data from the observation. It described the implementation of teaching speaking procedures that contained the process in teaching speaking procedure text that trough role-plays for the English lecturer and also describe the lecturer and the student's problem in teaching and learning procedure text.

3. The last analyzed the questionnaires. It explained the students' problem and response in learning speaking procedure text. The researcher collected the data by using a questionnaire for the student's assignment after finishing the class. The researcher analyzed the result of the questionnaire by using classification and percentage that states by Cresswell (2014) as follows:

$\mathbf{P}=\quad \mathbf{x} 100 \%$

Notes:

$\mathbf{N}$

P: Percentage of the respondents

F: Frequency of the students' answer

$\mathrm{N}$ : All the number of respondents

4. The researcher analyzed the data from the documentation by checking every meeting. The data contained the lecturer preparation before conducted the teaching and learning, and the researcher was taking the data for the lecturer to evaluate the students' work consist of group work and individual work.

\section{RESULT}

In this part, the researcher discussed two findings of this research. They are about the lecturer and second the students' data. The first data is about the lecturer's teaching preparation, teaching activities by using the role-play technique, the teaching problems, and the evaluation. The data about the students contained difficulties and opinions toward the teaching speaking skill in procedure text by using roleplay technique.

The Lecturer Preparation

Before the lecturer began teaching speaking skills in procedure text for the second-semester students, some preparations had finished. The lecturer had prepared all teaching preparation before he entered the classroom. The researcher used the interview instrument to know the lecturers' preparations. The data about lecturers' preparations in teaching and learning speaking activities obtained by the researcher were from the data of interview the lecturer, the observation data, and also the documentation data.

Based on the interview from the lecturer on December 12th, 2019. He stated that he always prepared the syllabus and learning contract. He prepared the materials, of course, related to the subject. The first preparation was designing the syllabus for speaking in the first semester. It had been prepared and developed by the lecturer at the beginning of the academic year.

The other preparation was the material.

The lecturer provided material related to the subject. The lecturer used whiteboards and pictures to support students' comprehension. The researcher interviewed the lecturer on December 12th, 2019. One of the questions was about the

100 | IJET| Volume. 9, Issue 1. July 2020

Copyright 2020 Putu Ngurah Rusmawan is licensed under Creative Commons Atrribution-ShareAlike 4.0 International License. 
lecturer technique to teach speaking sill.

The researcher observed in the classroom. The data took on December $11^{\text {st }}, 2019$, and December $12^{\text {nd }}, 2019$, during the teaching and learning process. The researcher entered the class, and he sat at the back. He observed the students' activity. The researcher used field notes to obtain data. Based on the observation, the lecturer prepared the syllabus and learning contract. They could support effective and efficient learning activities. The learning contract brought into the classroom.

The researcher collected the data documentation by using a checklist - the data collected from the syllabus and learning contract. In the syllabus, the lecturer stated the name of the course, semester, course description, objectives, the materials, learning outcomes, strategies, the assessment, the time allotment, and the learning sources. The process of teaching and learning about speaking in procedure text conducted in December. The researcher collected the research data on December $11^{\text {st, }} 2019$, until $12^{\text {nd }} 2019$. The data obtained from observation. Based on the result of a view, the lecturer used the roleplay technique in teaching speaking procedure text to enhance students' comprehension. The lecturer activities divided into three steps; they were opening, the main event, and closing. The time allotment for each meeting was $2 \times 50$ minutes.

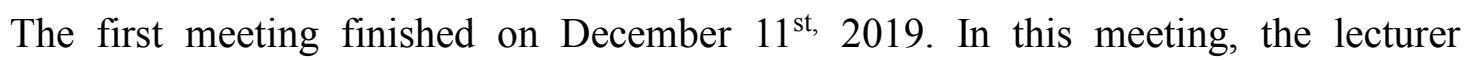
explained to the students about the topic of making hotel reservations. In the following, the researcher describes the teaching and learning process. The process of teaching divided into three steps; they were pre-activity, main activity, and post-activity.

\section{Pre-Activity ( 10 minutes)}

Before the lecturer was starting the teaching-learning process, the lecturer prepared and brought his learning contract and syllabus. In this activity, the lecturer and the students spent 10 minutes explaining the deal and short description of this course. Both of them during, classroom opening activities, seemed to enjoy the classroom process. The lecturer had succeeded in making the conducive classroom environment. It meant he made the classroom environment alive. The student seemed to have high motivation to follow the classroom teaching activities. The lecturer conducted opening teaching activities enthusiastically and warmly. The lecturer had grown the students' motivation. After the lecturer greeted the students, she began to check the students' attendance list. First, the lecturer greeted and asked the students to pray before the lesson started. Then, he prepared the students' condition mentally and physically. After that, the lecturer delivered learning objectives and instructions to the students.

\section{Main activities (80 minutes)}

The lecturer used the role-play technique by using scripted role-play. First, the lecturer gave the material by providing some examples of dialogue and related hotel reservation. Second, the lecturer explained to the students about the situation and condition in the hotel, especially in the front office. The lecturer told common expressions used in front office conversation, such as asking the information on hotel booking and requesting some foods and beverages. Third, the lecturer wrote some examples in a whiteboard and showed the way how to say and expressed it. Fourth, the lecturer asked the students to form a group and make the script of dialogue. Next, the students demonstrated and performed the conversation in front of the class with their group. Then, the lecturer gave comments, advice, and feedback to the students after they played in class. 
In the post-activity, The lecturer concluded the lesson. That was about material that had been done by the students in their role-play. The lecturer emphasized students' expression and pronunciation. After the lecturer closed the class and let the students leaving the course, the lecturer finished the lesson by reflecting the teaching main teaching activities. When the main teaching activities about describing a person would finish(10), the lecturer asked the students to discover the students' reflection by checking, and the students can respond well, they could reflect the lesson. The lecturer also gave positive feedback although the students' could reflect the experience, the students did not present their draft and collected their assignment this happened because the students' work had been terrible

Second Meeting (December, $12^{\text {nd }}$ 2019)

The second meeting finished on December 12th, 2019. In this meeting, the lecturer gave an explanation to the students about ordering the food. The process of teaching in this second meeting was conducted similarly with the ways of teaching done in the first meeting. The method of education consisted of three steps; they were pre-activity, main activity, and post-activity.

\section{Pre-Activity (10 minutes)}

In the pre-activity, the lecturer and the students spent 10 minutes. The lecturer greeted and checked the students' attendance. The lecturer needed to discover the students who were absent to check how many students would participate in her class. Since the lecturer wanted to test more whether they were playing truant or not, he began to ask the reason, and the students answered whether they were sick. The lecturer checked respectively to the students and tried to ask again to know and test the students' explanation of what kind of sickness. The students' answered well. Then, the lecturer explained the short description of the course to the students. The lecturer asked the students to pray first before the lesson began. The lecturer began to write in his presence list whether two of her students were absent today because they got sick. The lecturer began to explain the students' learning objectives that should be mastered and performed by the students after they had learned the lesson, and the students responded by acknowledged excitedly. Unfortunately, the lecturer's activities in preparing the students' mentally and physically finished finely. It could identify from her performance in the class. The did not give a short review of the way to make procedure text and link the previous material with the material that might help the students could be active participants and attracted the students' interest in the main teaching activities. He greeted the students, and the lecturer continued to the main events.

\section{Main Activities (80 minutes)}

In the main activity, the lecturer explained the material. In this meeting, the lecturer asked the students the problem by using the role-playing technique. The lecturer modified his role-play technique. The lecturer presented the slide that was about "asking, requesting, giving, and inviting the room division to deliver some foods and beverage," such as a picture of conversation between waiter and costumer, view of customer called, and responding room division. Then, he asked the student one by one about asking, requesting, and the waiter called. In meeting 1, the lecturer taught the students by scripted dialogue. In the meeting, two of the lecturer used role-play via picture information to activate the students' motivation in speaking. After the students made and performed the dialogue in front of the class. After finishing the 
students' performance, each student had got their feedback.

Post Activity (10 minutes)

In the post-activity, the lecturer summarized the activities that had finished in the classroom. The lecturer also asked the students about their difficulty in speaking procedure text. After that, the lecturer closed the class and let the students leaving the course. The lecturer began to direct the students to practice again at home for the students can explore the lesson back at home. Then, the students responded which, indicated affirmative acceptance. The lecturer followed up the students by directed to the students to work the assignment well

The Lecturers' Problems

Based on the researcher's interview with the lecturer on December 13th, 2019, the lecturer's problem in teaching speaking was the students had low vocabulary skills, little in pronunciations, and low skill to produce the sentences in requesting type. The students often chose to be silent. This condition occurred because they were afraid to make some mistakes. The lecturer should give them more motivation to speak up. All of the students obeyed the instruction from the lecturer.

The Students' Opinion Toward the Teaching and Learning Process.

The researcher described the students' opinions from the questionnaire. Below was the students' opinion about the lecturer teaching and learning speaking procedure text.

Table 4.1. Students' Opinion toward the technique types

\begin{tabular}{|l|l|l|}
\hline Question & $\begin{array}{l}\text { Students' } \\
\text { Response }\end{array}$ & Frequency \\
\hline $\begin{array}{l}\text { Do you like the lectures' } \\
\text { technique used by the }\end{array}$ & & \\
lecturer in teaching & & \\
speaking procedure text? & & \\
a. Yes, & & \\
b. Not Really & 24 & $70.5 \%$ \\
c. No & 10 & $29.5 \%$ \\
\hline
\end{tabular}

Table 4.1 above indicated that $70.5 \%$ of the students stated that they liked the lecture's technique in teaching speaking procedure text. While $29.5 \%$ of the students indicated that they did not like the technique. It could conclude that the students could recognize the lecture's technique. They comprehended the lecturer technique to teach speaking procedure text.

Table 4.2 The Students' Difficulty in Sentence Level Writing

\begin{tabular}{|l|l|l|}
\hline Question & Students' Response & Frequency \\
\hline $\begin{array}{l}\text { What kind of difficulty that you } \\
\text { found in speaking procedure }\end{array}$ & & \\
text? & 13 & $38 \%$ \\
a. Vocabulary & 10 & $29 \%$ \\
b. Pronunciation & 11 & $33 \%$ \\
c. expressing sentence & & \\
\hline
\end{tabular}

Table 4.2 above showed that $38 \%$ of students stated that vocabulary was the 
problem in speaking procedure text. While about $29 \%$ said that they had difficulty in their pronunciation, the others said that they had difficulty in expressing sentence. It could conclude that the problem faced in speaking procedure text was vocabulary.

Table 4.3 Students' Opinion about speaking Assessment

\begin{tabular}{|l|l|l|}
\hline Question & Students' Response & Frequency \\
\hline Do you know how the lecturer & & \\
assess your speaking? & & \\
a. Yes, & 10 & $29 \%$ \\
b. Not & 10 & $29 \%$ \\
c. No & 14 & $42 \%$ \\
\hline
\end{tabular}

Table 4.3 above showed that $42 \%$ of the students stated that the students didn't know whether the lecture assessed their speaking. $29 \%$ of the students stated that they knew whether the lecturer assessed their speaking. The left students stated that they didn't know whether the lecture assessed their speaking. The speech didn't inform about the process of assessing the students.

\section{The Evaluation of Teaching Speaking}

In the teaching-learning process, the lecturer evaluated the students' speaking by observing the students' pronunciation, expression, and the result of their performance. In the first meeting on $11^{\text {st }}$ of December and the second meeting on $12^{\text {nd }}$ of December, the lecturer asked the students to perform their script. The assignment consisted of the simulation practice between receptionists and customers. Lecturer evaluation and feedback were critical for the students to improve their speaking skills. Based on the documentation on $12^{\text {nd }}$ of December, it concluded that the lecturer gave evaluate to the students' speaking by focusing on pronunciation

\section{The Lecturer's Preparation in Teaching Speaking in procedure text.}

Based on the result of the interview with the lecturer, he had made teaching preparation. They were syllabus, learning contract, the material, and the media in teaching sentence-level writing course. Susanto (2010) stated the curriculum is a lesson plan for a group of subjects or specific themes which including standards of competence, basic competence, the subject matter of learning, learning activities, indicators, assessment, allocation of time and resources, or material. The first preparation consisted of a syllabus and learning contract to make an effective and efficient process.

The other preparation was the material. It was the conversation situation in the hotel. It consisted of hotel reservations, ordering, calling, and requesting. The third preparation was media. It could assist the students in transferring the knowledge delivered by the lecturer. The students could get a better comprehension. It made the students enjoy the course. By using the appropriate media, the process of teaching and learning became more active and alive. The lecturer had made enough preparation before the teaching and learning process.

\section{The Teaching process}

Based on the findings, it could conclude that the lecturer teaching process conducted into three steps, they were pre-activity, main activity, and post-activity. In preactivity, the lecturer was greeting, checking attendance, and explaining the learning contract. While in the main action, the lecturer taught by explaining script dialogue, showing the expression and conversation in the hotel situation, and direct the student to practices like a dramatic conversation between receptionist and costumer in a hotel. Last, the lecturer did the 
post-activity by giving motivation and closing. The lecture also using role-play technique training and simulation in the situation in the hotel to activate the students' speaking skills.

\section{The Problems in Teaching Speaking}

During the teaching and learning process, some problems should face. Based on the findings, the problem faced by the lecturer in teaching speaking at first semester students was a lack of vocabulary, pronunciation, and the students' difficulty in expressing sentences. Firstly, the lecturer was confused on how to deliver the material to the students who had low vocabulary mastery. Finally, the lecturer asked the students to memorize some vocabulary in the hotel. The other problem was the students'pronunciation. Then the lecture asked the students to imitate his pronunciation. Based on the observation in the first meeting and second meeting, some students still miss pronunciation. It proved when the lecturer asked the students to perform in front of the class. The lecturer should correct it, and also the lecturer reminded them about their pronunciation.

\section{The Students' Opinion toward the Teaching Speaking}

From the questionnaire which the researcher gave to them in the second meeting on December 12th, most of the students stated that teaching was already evident for the students and made them understand the material quickly. The result of data collection showed that 34 students were like the lecturer's role play technique of teaching and good response on the way of the lecturer's technique of teaching. It indicated that the lecturer conveyed the material was so bright and detail. Most of the students in the first semester were more interested in the lecturer's technique. In the learning activity, the lecturer also used the role-playing technique. It could conclude that the students needed guidance in learning speaking

\section{The Evaluation of the Teaching-Learning Process}

The lecturer evaluated the students' speaking by focusing on pronunciation. In short, the evaluation which had done by the lecturer was objective. The lecturer also preferred assessing the students' pronunciation and students' expressions when they performed their skill in front of the class. The lecture emphasized the students' pronunciation skills and students' speech. Grooming was a vital aspect to respect international tourists. That was why the lecturer also stressed on the students' expression.

\section{CONCLUSION}

The researcher could conclude that the speaking procedure text course, which was taught by the lecturer, proceeded effectively and acceptable for the students. As proof of the research, the researcher shows the result of the lecturers' preparation, the lecturing, the problems, the solution, opinion, and problems of students.

The preparation of the lecturer was syllabus and learning contract, which contained teaching materials, the method, and learning sources. The process of teaching divided into three steps; they were pre-activity, main activity, and post-activity. He brought them in class.

The lecturer used the role-playing technique. He enjoyed the teaching and learning process and got all of the students'attention in the process of teaching speaking procedure text. The lecturer only facilitated the students to be motivated to learn speaking procedure text. During the teaching-learning process, the lecturer got three main troubles in conducting the teaching process. They were students' low in vocabulary, pronunciation, and the students' difficulty in expressing sentences, and the lecturer had done the solution. The lecturer always

gave feedback in the students' performance, and he often made the student remember about how to pronounce well by providing an example of the correct pronunciation before the

105 | IJET| Volume. 9, Issue 1. July 2020 Copyright 2020 Putu Ngurah Rusmawan is licensed under Creative Commons Atrribution-ShareAlike 4.0 International License. 
students' performance. The lecturer always gave a chance to the students who were afraid to perform, but they still did not have confidence, and they were afraid to make a mistake. 


\section{REFERENCES}

Anderson, M., \& Anderson, K. (2003). Text Types in English 1. Sydney: McGraw-Hill. Book Company.

Brown, H. D. (2007). Teaching By Principle: An Interaction Approach to Language Pedagogy. New York: Addition Wesley Longman, Inc.

Burke Johnson. L. Christensen. (2007). Educational Research: Quantitative, Qualitative, and Mixed Approaches. New York: Sage Publication.

Cresswell, J. W. (2014). Research Design: Quantitative, Qualitative, and Mixed Methods Approaches 4th edition. New York: Sage Publications, Inc.

Harmer, J. (2007). How to Teach English. Edinburg: Pearson Longman.

Susanto. (2010a). Konsep Penelitian Tindakan Kelas dan Penerapannya. Surabaya: Unesa University Press.

Susanto. (2010b). Silabus \& RPP: Mata Pelajaran Bahasa Inggris untuk SD/MI, SMP/MTS, $S M A / M A$ dan $S M K / M A K$. Surabaya: Fakultas Bahasa dan Seni Universitas Surabaya.

Ur P. (2012). Course in English Language Teaching; 2 edition. Cambridge University Press.

Yule, G. (2010). The Study of Language. London: Cambridge University Press. 